\title{
COMPARATIVE RESOURCE PRODUCTIVITY OF OYSTER (PLEUROTUS OSTREATUS P.) AND BUTTON MUSHROOMS (AGARICUS BISPORUS J.) IN KATHMANDU, NEPAL
}

\author{
Lal K. Shrestha ${ }^{1}$ and Shiva C. Dhakal ${ }^{2}$
}

\begin{abstract}
The study was conducted to analyze the comparative economics of oyster (Pleurotus ostreatus P.) and button mushrooms (Agaricus bisporus J.) in Kathmandu district of Nepal during the year 2012 with the objective to compare their resource productivity. Primary data were collected from semi-structured pretested questionnaire from purposively selected 45 growers from each category. The examination of resource use efficiency showed that most of the resources were not used efficiently and there is further scope of commercialization. It is imperative to banks for investment in mushroom. Study revealed materials are to be decreased in case of oyster mushroom and labor use is to be increased in button mushroom. It is suggested to cultivate button mushroom instead of oyster as button mushroom has increasing return to scale. It was concluded that the mushroom farming was highly profitable and suggested to cultivate button mushroom in long run and oyster mushroom in short run.
\end{abstract}

Key Words: resource productivity, resources use efficiency, returns to scale, mushroom

\section{INTRODUCTION}

Agriculture is the foundation of Nepalese economy contributing 38 percent of GDP and provides employment and livelihood to 65.6 percent of economically active population (CBS, 2011). The economic growth of the country measured by GDP is 4.63 percent per year in the year 2011/12. About one fourth of the population (25.16 percent) lives below poverty line as per the Nepal Living Standards Survey 2010/11 and the Gini-Coefficient; which indicates inequality in income distribution, is 0.328 (CBS 2012). Government of Nepal has also accorded a top priority to commercialization of agriculture and development of high value cash crops as envisaged in the Agricultural Perspective Plan (APP).

The first cultivation of mushrooms is in China around $600 \mathrm{AD}$ with the Auricularia auricula on wood logs (Neupane, 2068). Cultivation of mushroom in Nepal is Agaricus bisporus (1979/1980), Volveriella volvacea (1982) and Pleurotus sajorcaju -1983/84. Shitake (Lentinus edodes) has also been cultivated though on a very limited scale. Production is concentrated in urban and peri-urban areas (Dhakal, 2008). In Nepal, 760 species of mushrooms have already been recorded as wild. Of these, 170 species have been tested and proven as 'edible mushrooms'. However, only a few species have a high demand from abroad (Poudel and Bajrachayra, 2011).

\footnotetext{
1 Senior Agri Economist, Mo nitoring and Evaluation Division, MoAD, email shresthalk@yahoo.com

${ }^{2}$ Asst. Prof. (Department of Agricultural Economics), IAAS Rampur, Chitwan Nepal
} 
Mushroom cultivation was initiated by the Division of Plant Pathology, Nepal Agricultural Research Council (NARC) in 1974. The growing technology for white button mushroom was developed during that early period and extended to general farmers starting in 1977. Oyster mushroom was introduced to farmers in 1984. In the beginning a handful of farmers started this farming in Bhaktapur and Kathmandu district. But today there are numerous farmers in mushroom cultivation. World total production was 7540 thousand metric tons in 2011. Out of total production China has 66.42 percent share and followed by Italy 10.10 percent of world production (FAOSTAT, 2011).

Mushroom cultivation is more popular as income generating activities among limited Nepalese farmers. Among the different crops mushroom (commonly known as Chyau) is newly emerging crop becoming most popular at now. It is used in different ceremony as special dish and especially more used by vegetarian peoples. The total production of mushroom in Nepal is 1600 metric tons (DolED, 2011). Out of total mushroom production, bottom mushroom occupies 25 percent and oyster mushroom occupies 75 percent in the country.

The market infrastructures, market information, scale of marketable surplus and its quality, cost of production, product competitiveness etc. are other areas of growing challenges in agriculture in order to promote it as a business. It is most popular commodity of Kathmandu district. Per annum mushroom production in Kathmandu is 850 metric tons in Kathmandu. More than 600 farmers are involved in mushroom production (DADO, 2012).

Heady (1964) explained the condition of maximum efficiency that whether or not the economic quantity to be maximized is profit, the resources must be distributed between all of these units in a manner such that their marginal productivity is equal to all cases. Resources are allocated most efficiently when these conditions hold true: firstly resources must be allocated within each farm in a manner so that the marginal value productivities of the resource services are equal. Secondly, resources must be distributed between farms so that marginal value productivities are equal. Thirdly, resources must be distributed between producing and farming areas to allow attainment of equal value productivity. Fourthly, the various factors must be allocated between industries to bring about attainment of these identical conditions and lastly resources must be allocated over time such that discounted value products are equal.

Dhakal (2006) explained, about the resource use efficiency, in his research on socio-economic and financial feasibility of tractorization in Chitwan district that the human and tractor labor used were positive and non-significant on tractor farms. Cash expenses variable was estimated to be negative but, significant on tractor farms. As the deviation of prices of resources from their respective marginal value productivities were non-significant, these resources were found to be efficiently used on tractor farms. In case of bullock farms, the elasticity of production of cash expenses had positive and significant coefficient and, deviation of price of cash expenses from its marginal value productivity was significant, indicating inefficient use of cash on bullock farms. 
On the comparative rate of return on investment of the different management level, high-level management of green corn, lettuce, sweet pepper and snap beans is advantageous compared to medium-input technology, however mediuminput management of sweet potato, carrots, tomato, cabbage and sweet peas are advantageous compared to high-input management (Osip, 2003).

For production under a given technological environment with both output and input variable, the ideal measure of the efficiency of resources use is provided by the marginal return to opportunity cost ratios of the various resources. Concomitantly, these ratios indicate the direction of changes that should be made in resource allocation if profits are to be maximized (Heady, 1964).

The findings would be helpful to the farmers for correcting weakness and make effective plan for resource use for mushroom cultivation. This would also help policy makers, farmers, mushroom processing industries, and academic institutions. In this context, the major objective of the study was to assess the comparative resource productivity of oyster and button mushrooms in Kathmandu district.

\section{RESEARCH METHODOLOGY}

This study was carried out in Kathmandu Nepal during June 2012. Balambu, Thankot and Tokha Sarswoti VDCs were purposively selected for the study due to (i) potentiality of producing mushroom (ii) easily accessible and (iii) cultivation of different type in each location. Respondents were of two categories namely, commercial farmers and traders. From all the mushroom growing farmers' from selected VDCs total sample of 90 farmers were selected randomly in proportionate with the size of subpopulation for each type of mushroom grower. Simple random sampling technique without replacement was followed.

Various sources and techniques were used for collection of necessary information. In this study, both the primary and secondary data were collected and analyzed. In order to carry out any research and draw reliable and meaningful conclusion, it is very much essential that the methods and techniques of data collection be precise and accurate. Different techniques such as interview, group discussion, key informants survey and informal interaction methods were used for the collection of necessary information. The socio-demographic and farm characteristics like family size, sex and age distribution, occupation, education level, size of land holding etc. were analyzed by using descriptive tools, like frequencies, percentage, means and standard deviation wherever applicable. CobDouglas production function was used to find the productivity and resource use efficiency. Excel was used for data set preparation and handling, and STATA software was used for further analyses. The following analyses were done.

\section{RESOURCE PRODUCTIVITY}

In order to examine resource use efficiency on mushroom cultivation, regression analysis technique was used. The Cobb-Douglas forms of production functions was used because of higher coefficient of multiple determinations $\left(R^{2}\right)$ and, retaining 
more number of significant explanatory variables to calculate marginal value productivities as indicator of resource use efficiency in each category of farm. Resource productivity and return to scale was calculated by using Cobb Douglas form of production function.

$\mathrm{Y}=a \mathrm{x}_{1}{ }^{\mathrm{b} 1} \mathrm{x}_{2}^{\mathrm{b} 2} \mathrm{e}^{\mathrm{u}}$

Where, $\mathrm{Y}=$ mushroom production $(\mathrm{kg})$

$$
\begin{aligned}
& \mathrm{X}_{1}=\text { Labour (man days) } \\
& \mathrm{X}_{2}=\text { material expenses (Rs.) } \\
& \mathrm{e}=\text { Error term } \\
& \mathrm{a}, \mathrm{b}_{1}, \mathrm{~b}_{2}, \mathrm{u}=\text { parameters to be estimated. }
\end{aligned}
$$

If $\left(B_{1}+B_{2}\right)=1$, there is constant return to scale.

If $\left(B_{1}+B_{2}\right)<1$, there is decreasing return to scale.

If $\left(B_{1}+B_{2}\right)>1$, there is increasing return to scale.

\section{RESULTS AND DISCUSSIONS}

The collected information was analyzed as per objective using proper statistical tool and the results have been presented in this section.

\section{SOCIO-ECONOMIC CHARACTERISTICS OF THE RESPONDENTS}

The socio economic characteristic of respondents include population and gender, family size, economically active population, education, occupation, ethnicity, land holding, farming experience.

\section{POPULATION DISTRIBUTION}

The total population of sampled household in the study area was found to be 433 , out of which 52.7 percent were male and 47.3 percent female. In case of Balambu VDC, total population of sampled household was 328, out of which 53.4 percent were male and 46.6 percent female. In Thankot VDC, total population was 52 out of which 48.1 percent were male and 51.9 percent female. Similarly, in Tokha Saraswoti VDC, total population was 53 out of which 52.8 percent were male and 47.2 percent female. The distribution of the population of the sampled households by gender and VDC is presented in Table 1. 
Table 1. Population distribution in sampled household by gender across 3 VDCs

\begin{tabular}{lclll}
\hline \multirow{2}{*}{ VDC } & \multicolumn{2}{c}{ Gender } & Total & \multirow{2}{*}{$\begin{array}{c}\text { Average } \\
\text { family size }\end{array}$} \\
\cline { 2 - 4 } & \multicolumn{1}{c}{ Male } & Female & & \\
\hline Balambu & $175(53.4)$ & $153(46.6)$ & $328(75.8)$ & 5.0 \\
Thankot & $25(48.1)$ & $27(51.9)$ & $52(12.0)$ & 4.7 \\
Tokha Saraswoti & $28(52.8)$ & $25(47.2)$ & $53(12.2)$ & 4.1 \\
\hline Total & $228(52.7)$ & $205(47.3)$ & $433(100.0)$ & 4.6 \\
\hline
\end{tabular}

Figure in parentheses indicate percentage

FAMILY SIZE

Family size plays vital role in farming community. Labor is the most important input for farm operation. The number of labor a family can supply for operation is determined by its family size. The average family size of the respondents was 4.81, relatively lesser compared to the national average of 4.88 and district average 4.0 of Kathmandu (CBS, 2011). The average family size of button mushroom farming farmers was higher than oyster mushroom farming farmers.

\section{ECONOMICALLY ACTIVE POPULATION}

Based on the total population of the sampled households, it was categorized into three age groups. Among these categories the economically active population referred to the population belonging to the age group of 15-59 years. It was found that 65.1 percent of population were economically active, which was lesser than the district average of 73.6 percent (CBS, 2011). By VDC, the economically active population was found higher in Tokha Saraswoti $(75.5 \%)$ in comparison to Balambu VDC (62.8\%) and Thankot VDC (69.2\%). The majority of the population was seen in economically active category. This is also supported by CBS (2011) data as economically active population is $70.19 \%$ in Kathmandu. Population of sampled household by age group and location has been presented in Table 2 .

Table 2. Population of sampled household by age group across the 3 VDCs

\begin{tabular}{lllll}
\hline $\begin{array}{l}\text { Age } \\
\text { group }\end{array}$ & Balambu & Thankot & $\begin{array}{l}\text { Tokha } \\
\text { Sarswoti }\end{array}$ & Total \\
\hline $\begin{array}{l}<15 \\
\text { years }\end{array}$ & 90 & $9(17.3)$ & $8(15.1)$ & $107(24.7)$ \\
$15-59$ & 206 & 36 & 40 & $282(65.1)$ \\
years & $(62.8)$ & $(69.2)$ & $(75.5)$ & $44(10.2)$ \\
$>59$ & $32(9.8)$ & $7(13.5)$ & $5(5.0)$ & $433(100.0)$ \\
years & & 52 & 53 & $(100.0)$ \\
\hline Total & 328 & $(100.0)$ & & Field Survey 2012 \\
\hline Figure in parentheses indicate percentage &
\end{tabular}

\section{EDUCATIONAL LEVEL OF FAMILY}

The result showed that, the literacy rate of surveyed households was 71.1 percent which was lesser than district average of 77.0 percent. The majority of the respondent had secondary level education. Higher the literacy rate higher will be 
the technology adoption rate. The educational attainment of sampled household by VDC is represented in Table 3.

\section{EDUCATIONAL LEVEL OF HOUSEHOLD'S HEAD}

About 8.9 percent of the respondent household's heads acquired primary level education in the study area. 2.2 percent household's head were found illiterate. Out of total 52.2 percent acquired secondary education and 36.7 percent had obtained secondary level education. The overall literacy rate of household head was 97.8 percent. There was 100 percent literacy in oyster mushroom farming area where as only 95.6 percent in the button mushroom farming area.

Table 3. Educational level of the of sampled household across 3 VDCs

\begin{tabular}{lllll}
\multirow{2}{*}{ Education level } & \multicolumn{3}{c}{ VDC } & \multicolumn{1}{c}{ Total } \\
\cline { 2 - 5 } & Balambu & Thankot & Tokha Sarswoti \\
\hline Illiterate & $100(30.5)$ & $13(25.0)$ & $12(22.6)$ & $125(28.9)$ \\
Literate & $49(14.9)$ & $6(11.5)$ & $13(24.5)$ & $68(15.7)$ \\
Primary & $58(17.7)$ & $17(32.7)$ & $15(28.3)$ & $90(20.8)$ \\
Secondary & $73(22.3)$ & $13(25.0)$ & $11(20.8)$ & $97(22.4)$ \\
Above Secondary & $48(14.6)$ & $3(5.8)$ & $2(3.8)$ & $53(12.2)$ \\
\hline \multicolumn{1}{c}{ Total } & $328(100.0)$ & $52(100.0)$ & $53(100.0)$ & $433(100.0)$ \\
\hline
\end{tabular}

Figure in parentheses indicate percentage

Field Survey 2012

\section{OCCUPATION OF THE FAMILY MEMBERS}

According to the result of the study it was found that 24.0 percent of the family members were students, 58.9 percent of population was employed in agriculture. The main occupation of 9.5 percent respondent family at different location was agriculture, followed by students and services (9.5\%). A very few farm families members were engaged in business (3.7\%). About 3.9 percent sampled population engaged on aboard and others. Other occupation refers to daily wage labor and children. The occupational pattern of sampled household has been presented in Table 4.

Table 4. Occupational pattern of sampled household across 3 VDCs

\begin{tabular}{lllll}
\hline \multirow{2}{*}{ Occupation } & \multicolumn{3}{c}{ VDC } & Total \\
\cline { 2 - 5 } & Balambu & Thankot & Tokha Saraswoti & \\
\hline Agriculture & $192(58.5)$ & $32(61.5)$ & $31(38.5)$ & $155(58.9)$ \\
Business & $13(4.0)$ & $2(3.8)$ & $1(1.9)$ & $16(3.7)$ \\
Service & $34(10.4)$ & $3(5.8)$ & $4(7.5)$ & $41(9.5)$ \\
Students & $76(23.2)$ & $13(25.0)$ & $15(28.3)$ & $104(24.0)$ \\
Aboard and others & $13(4.0)$ & $2(3.8)$ & $2(3.8)$ & $17(3.9)$ \\
\hline Total & $328(100.0)$ & $52(100.0)$ & $53(100.0)$ & $433(100.0)$ \\
\hline
\end{tabular}

Figure in parentheses indicate percentage Field Survey 2012 


\section{LAND HOLDING OF SAMPLED HOUSEHOLDS}

The average land holding of the surveyed sample was 3.9 ropani (Table 5). Table shows that own land was 2.37 ropani per household and 6.5 ropani were rented in by the farmers. The average land holding and rented in land was higher in Thankot as compared to Balambu and Tokha Saraswoti. The total average land of surveyed sample was 3.9 ropani where in owned average land was 2.4 ropani and rented average land 6.5 ropani.

Table 5. Land holding of sampled household across 3 VDCs

\begin{tabular}{llll}
\hline VDC & $\begin{array}{l}\text { Owned } \\
\text { land } \\
\text { (ropani) }\end{array}$ & $\begin{array}{l}\text { Land rented } \\
\text { in (ropani) }\end{array}$ & $\begin{array}{l}\text { Total used } \\
\text { land (ropani) }\end{array}$ \\
\hline Balambu & 2.4 & 7.2 & 3.8 \\
Thankot & 2.6 & 8.3 & 5.5 \\
Tokha Saraswoti & 1.8 & 3.8 & 3.0 \\
\hline Total & 2.4 & 6.5 & 3.9 \\
\hline
\end{tabular}

Field Survey 2012

The average land holding of the surveyed sample was 3.9 ropani (Table 5). Out of this, Oyster mushroom growing household have 4.9 ropani which is higher than the Button mushroom grower i e 2.9 ropani. Table 6 shows that own land was 2.5 ropani per household and 6.5 ropani were rented in by the farmers. The average land holding and rented in land was higher in oyster mushroom as compared to Button mushroom.

Table 6. Av. land holding (ropani) of sampled household according to mushroom types

\begin{tabular}{llll}
\hline VDC & Owned land (ropani) & Land rented in (ropani) & $\begin{array}{l}\text { Total used land } \\
\text { (ropani) }\end{array}$ \\
\hline Button & 2.5 & 4.4 & 2.9 \\
Oyster & 2.7 & 7.7 & 4.9 \\
\hline Total & 2.5 & 6.5 & 3.9 \\
\hline
\end{tabular}

Field Survey 2012

\section{ETHNICITY OF THE SAMPLED HOUSEHOLDS}

Brahamin, Chhetri and Aadibasi/ janajati were main ethnic group in the study area (Table 7). Among them the majority was Aadibasi/janajati (57.8\%) followed by Chhetri (23.3\%) and Brahamin (18.9\%). In all VDCs, Adibasi/Janajati was the dominant ethnic group. 
Table 7. Ethnicity of sampled household across 3 VDCs

\begin{tabular}{|c|c|c|c|c|c|}
\hline \multirow{2}{*}{ Ethnicity } & \multicolumn{5}{|c|}{ VDC } \\
\hline & Balambu & Thankot & & Tokha Sarswoti & Total \\
\hline Aadibasi / Janajati & $33(50.0)$ & $10(90.9)$ & & $9(69.2)$ & $52(57.8)$ \\
\hline Bramin & $14(21.2)$ & 0 & & $3(23.1)$ & 17 (18.9) \\
\hline Chhetri & $19(28.8)$ & $1(9.1)$ & & $1(7.7)$ & $21(23.3)$ \\
\hline Total & $66(100.0)$ & & $11(100.0)$ & $13(100.0)$ & $90(100.0)$ \\
\hline
\end{tabular}

Figure in parentheses indicate percentage

Field Survey 2012

\section{FARMING EXPERIENCES}

Experience is very important which plays the vital role in farming. Quality and quantity of production, adoption of new technology and technology transfer rate depends upon the farmer's experience. It was observed that among the surveyed household farmers had up to 25 years of experience in mushroom farming. By location, the farmers were found more experienced in Balambu VDC compared to Thankot and Tokha Sarswoti VDC on basis of year of mushroom farming. Majority of the farmers had 5-10 years of experience in both types of mushroom farming. However majority of the respondents got involved in mushroom farming recently. Details are given in Table 8.

Table 8. Farmer's experience on mushroom cultivation across 3 VDCs

\begin{tabular}{|c|c|c|c|}
\hline \multirow{2}{*}{ Experience } & \multicolumn{2}{|c|}{ Types of mushroom } & \multirow[b]{2}{*}{ Total $(\mathrm{N}=90)$} \\
\hline & Button $(n=45)$ & Oyster $(n=45)$ & \\
\hline $\begin{array}{l}<5 \text { years } \\
5-10 \text { years }\end{array}$ & $\begin{array}{l}14(31.1) \\
25(55.6)\end{array}$ & $\begin{array}{l}13(28.9) \\
21(46.7)\end{array}$ & $\begin{array}{l}27(30.0) \\
4651.1)\end{array}$ \\
\hline$>10$ years & $6(13,3)$ & $11(24.4)$ & 17 (18.9) \\
\hline Total & $45(100)$ & 45 (100) & $90(100)$ \\
\hline
\end{tabular}

Figure in parentheses indicate percentage Field Survey 2012

\section{RESOURCE PRODUCTIVITY}

The results of estimated production functions of the Cobb-Douglas form have been discussed in this section. As mentioned earlier, the gross cash income from mushroom was taken as dependent variable and material cost in mushroom production, per year human labor absorption in mushroom production were taken as explanatory variables.

An examination of coefficient of multiple determinations $\left(R^{2}\right)$ indicates that the explanatory variables included in regression model were responsible for about 89.01 percent and 96.48 percent variation in gross cash income from button mushroom and oyster mushroom respectively. The regression coefficients and marginal value productivities of individual explanatory variable are discussed below. 
The Cobb-Douglas production function was used in the computation of Marginal Value Product (MVP) of the resources used in mushroom production. The results of resource use efficiency are presented in table below.

\section{Human labor}

The regression coefficient of human labor was observed to be 0.74 and 0.07 indicating if human labor was increased by 1 percent it increased gross cash income by 0.74 and 0.07 percent in button and oyster mushroom respectively.

At 5 percent level of significance $t$-calculated (6.27) was greater than t-tabulated (2.05) in button mushroom but in case of oyster mushroom, t-calculated $(0.97)$ was smaller than t-tabulated (2.05) in oyster mushroom. This indicated that difference was found to be statistically significant in button mushroom but there was found to be statistically non significant in case of oyster mushroom and hence, there existed resource use efficiency in oyster mushroom and vice versa in button mushroom.

Regression equation of button mushroom is $y=0.81 \mathrm{M}^{0.35} \mathrm{~L}^{0.74}$

\section{Material cost}

The regression coefficient of material cost in button mushroom appeared to be 0.35 and 0.88 in oyster mushroom indicating if material cost was increased by 1 percent it increased gross cash income by 0.35 and 0.88 percent in these mushroom respectively.

At 5 percent level of significance, t-calculated (2.89) was greater than t-tabulated (2.05) in button mushroom and also t-calculated (11.78) was greater than ttabulated (2.05) in oyster mushroom. The deviation of marginal value productivity of cash expenses from its price was statistically non-significant indicating efficiency in use of cash on mushroom production.

Regression equation of oyster mushroom is $y=1.08 \mathrm{M}^{0.88} \mathrm{~L}^{0.07}$

Hence, the expenses on fixed items on mushroom production were used efficiently. The examination of resource use efficiency in the research sites showed the most of the resources were not used efficiently and there are greater chances to promote the commercial cultivation of mushroom. It would be the better field for financial institutions to focus their investment program. The estimated Cobb-Douglas production functions marginal value products (MVP) of resources on mushroom production in Table 9 and 10.

Table 9. Marginal value products of resources on button mushroom production from CobbDouglas production functions

\begin{tabular}{lllll}
\hline Total return & Coefficient & Std Err. & $\mathrm{t}$ & $\mathrm{P}>|\mathrm{t}|$ \\
\hline Material cost & 0.35 & 0.12 & 2.89 & 0.01 \\
Labor cost & 0.74 & 0.12 & 6.27 & 0.00 \\
Constant & 0.81 & 0.28 & 2.88 & 0.01 \\
\hline R-square $=0.89$ & & & & Field Survey 2012 \\
= $0.81 \mathrm{M} 0.35 \mathrm{~L} \mathrm{0.74}$ & &
\end{tabular}


Result revealed increasing return to scale on oyster mushroom cultivation. Dhakal (2006) explained, about the resource use efficiency, in his research on socioeconomic and financial feasibility of tractorization in Chitwan district that the human and tractor labor used were positive and non-significant on tractor farms.

Result revealed increasing return to scale on button mushroom cultivation.

Table 10. Marginal value products of resources on oyster mushroom production from CobbDouglas production functions

\begin{tabular}{lllll}
\hline Total return & Coefficient & Std Err. & $\mathrm{t}$ & $\mathrm{P}>|\mathrm{t}|$ \\
\hline Material cost & 0.88 & 0.07 & 11.78 & 0.00 \\
Labor cost & 0.07 & 0.07 & 0.97 & 0.34 \\
Constant & 1.08 & 0.15 & 7.00 & 0.00 \\
\hline
\end{tabular}

R-square $=0.96$

$\mathrm{y}=1.08 \mathrm{M} 0.88 \mathrm{~L} 0.07$

\section{CONCLUSION}

The examination of resource use efficiency in the study area showed the most of the resources are not used efficiently and there are greater chances to promote the commercial cultivation of mushroom. It indicated positive sign for financial institution to invest in this sector. Study revealed materials are needed to be subsidized or to be increased in efficiency in case of oyster mushroom and in case of button mushroom labors are needed to be increased in efficiency or subsidized. As study resulted in increasing return to scale on button mushroom and decreasing return to scale on oyster mushroom such that it is conclude that cultivation of button mushroom instead of oyster. Farmers willing to invest for long time then he /she is suggested to cultivate button mushroom and for short term suggested to cultivate oyster mushroom.

\section{ACKNOWLEDGEMENT}

We are thankful to Dean, IAAS; Academic Dean, IAAS; members of advisory committee, Department of Agricultural Economics, District Agriculture Development Office Kathmandu, Department of Agriculture, Ministry of Agricultural Development, Colleagues, respondents of Kathmandu and my family.

\section{REFERENCES}

CBS. 2011. Population census preliminary report of Nepal 2011. Central Bureau of Statistics, National Planning Commission Secretariat. Government of Nepal. Thapathali, Kathmandu, Nepal.

CBS. 2012. National Population and Housing Census 2011 (National Report). Central Bureau of Statistics, National Planning Commission Secretariat, GoN, Kathmandu, Nepal. pp. 1-4,39-41. Website:http://cbs.gov.np/wp-content/uploads/2012/11/

National\%20Report.pdf [Retrieved at 2 May 2013].

DADO. 2012. District Agriculture Statistics Data Book. District Agriculture Development Office, Kathmandu. pp. 1-6. 
DADO. 2012. Annual Agricultural Development Programs and Statistics: A Glimpse (In Nepali). Government of Nepal, Ministry of Agricultural Development, Department of Agriculture. District Agriculture Development Office, Kathmandu, Nepal.

Dhakal, A. P. 2008. Mushroom Development, Future Prospects and Marketing System of Nepal. A paper presented at National Workshop on Mushroom Development organized by DolED in June 14, 2008. Directorate of Industrial Entomology Development, Hariharbhawan, Lalitpur, Nepal.

Dhakal,S.C. 2006. Socio-economic impact and financial feasibility of tractorization in Chitwan district, Nepal., M. Sc. Thesis, G.B. Panta University of Agriculture and Technology, Pantanagar, Uttranchal, India.pp. 27.

DolED. 2011. Byabasahik kit bikas karyakramko parichaya, uplabdhi tatha karayabidhi 2068 (in Nepali). Diractorate of Industrial Entomology Development, Hariharbhawan, Lalitpur, Nepal. pp 5-6, 101-103, 125-133. Website: http://www.doiednepal.gov. np. [Retrieved at 11 June 2013].

FAO. 2012. FOOD AND AGRICULTURE ORGANIZATION OF THE UNITED NATIONS. for a world without hunger. Headquarters Viale delle Terme di Caracalla 00153 Rome, Italy. Website: http://faostat.fao.org/site/339/default.aspx [Retrieved at 11 June 2013].

Heady, E. O.1964. Economics of agricultural production and resource use. Prentice-Hall of India Pvt. Ltd. Pp. 704-707.

Neupane, S. P. Nepal ma Chyua Kheti. Binita Neupane, Kathmandu, 2068.

Osip, C.A. 2003. Technology commercialization on high-value vegetables, young corn and sweet potato production. Department of Agriculture. Abstracts of Nomcarrd Researches. Website: http://.nomcarrd.org/index.php?option=com...view...2003... [Retrieved on 9 September 2012].

Poudel, S. and A. Bajracharya. 2011. Prospects and Challenges of mushroom cultivation in Nepal: A case study of Lakuri Bhanjyang, Lalitpur. A paper presented to Environment Veteran Firm (EVF), Japan and Nepal-Japan Project Team members at Tokyo City University, Japan. Website: www.forestrynepal.org [Retrieved at 24 December 2012] 